\title{
PENGARUH UNSUR ALUMINIUM DALAM KUNINGAN TERHADAP KEKERASAN, KEKUATAN TARIK, DAN STRUKTUR MIKRO
}

\author{
Eko Nugroho \\ Jurusan Teknik Mesin, Fakultas Teknik, Univ. Muh Metro \\ Jl. Ki Hajar Dewantara no 115 Metro \\ E-mail exonugros@yahoo.co.id
}

\begin{abstract}
Abstrak
Kuningan yang merupakan logam non ferro banyak digunakan dalam industri. Kuningan merupakan logam paduan tembaga dan seng dengan lebih dari $50 \%$ tembaga dan seng sebagai logam pemadu utama. Penambahan unsur aluminium pada kuningan bertujuan untuk meningkatkan kekerasan dan kekuatannya. Pelaksanaan penelitian, aluminium akan dicampurkan kedalam kuningan dengan komposisi $1 \%$ dan $3 \%$ saja. Untuk menambahkan unsur aluminium kedalam kuningan dilakukan proses pengecoran. Pengujian dilakukan dengan mempersiapkan tiga buah spesimen dengan komposisi yang berbeda yaitu kuningan tanpa penambahan unsur aluminium, kuningan dengan penambahan $1 \%$ unsur aluminium, dan kuningan dengan penambahan 3\% unsur aluminium. Kemudian dilakukan pengujian kekerasan, kekuatan tarik, dan metallografi terhadap benda uji sehingga didapat data dari pengujian yang dilakukan. Hasil penelitian dapat diketahui bahwa penambahan unsur aluminium mengakibatkan kuningan mengalami peningkatan kekerasan dan kekuatan. Nilai kekerasan menjadi meningkat dari 91,152 VHN sampai 95,693 VHN, kekuatan tarik menjadi meningkat dari $26,274 \mathrm{kgf} / \mathrm{mm}^{2}$ sampai $27,229 \mathrm{kgf} / \mathrm{mm}^{2}$. Hasil pengamatan struktur mikro didapat besar butir kuningan menjadi lebih halus.
\end{abstract}

Kata Kunci : Aluminium, Kuningan, Kekerasan, Uji Tarik, Uji Struktur Mikro.

\section{Pendahuluan}

Seiring dengan perkembangan IPTEK yang sedemikian pesat dewasa ini , merupakan tantangan bagi bangsa Indonesia dalam rangka mensukseskan pembangunan nasional yang salah satu titik beratnya adalah dibidang industri. Pemilihan bermacam-macam ragam bahan atau material logam yang biasa dipergunakan sebagai bahan industri menjadi fenomena didalam proses produksi. Pemilihan material tidak hanya berdasarkan pertimbangan teknik semata tetapi dari segi ekonomisnya perlu dipertimbangkan . Penentuan material yang tepat pada dasarnya merupakan kompromi antara berbagai sifat bahan yang dapat memenuhi syarat yang telah ditentukan . Hal ini telah memacu para ahli dibidang metallurgi untuk menciptakan teknologi meningkatkan kemampuan material sesuai manfaat yang diinginkan untuk mencapai hasil yang optimal. Guna menunjang teknologi tersebut, keberadaan logam sangat penting untuk menunjang sektor industri, terutama logam non ferrous.

Salah satu logam non ferrous yang digunakan sebagai komponen-komponen mesin maupun kerajinan adalah kuningan. Kuningan merupakan paduan tembaga dan seng dengan lebih $50 \%$ tembaga, dan seng sebagai logam paduan utama.

Kuningan banyak digunakan karena kuningan mempunyai ketahanan korosi dan ketahanan aus yang baik. Selain itu mampu cornya juga baik, sehingga bahan ini banyak digunakan. Dalam kesempatan ini akan dilakukan penelitian dan percobaan dengan menambah aluminium pada proses pengecoran sebagai bahan pengikat pada kuningan.

Karena itu perlu dilakukan analisa seberapa besar pengaruh unsur aluminium dalam kuningan terhadap perubahan sifat mekanik dari kuningan tersebut. Hal ini sangat diperlukan untuk mengetahui gejala yang timbul terhadap perubahan sifat mekanik kuningan sehingga penggunaan kuningan dalam berbagai bidang industri dapat lebih. 


\section{Tinjauan Pustaka}

\section{Kuningan}

Kuningan merupakan paduan dari tembaga $(\mathrm{Cu})$ dengan seng $(\mathrm{Zn})$. Perubahan prosentase $\mathrm{Zn}$ dalam paduan tersebut, menyebabkan perubahan sifat-sifat dari kuningan tersebut, baik fisik maupun mekanik.

Untuk mendapatkan kuningan istimewa maka ditambahkan logam-logam tertentu. Logam-logam yang biasa ditambahkan atau dipadukan pada kuningan antara lain : Aluminium ( $\mathrm{Al}$ ), Plumbum ( $\mathrm{Pb}$ ), Mangan ( Mn ), Nikel ( Ni ), dengan maksud untuk mendapatkan sifat-sifat yang diinginkan.

Berdasarkan diagram fasa $\mathrm{Cu}-\mathrm{Zn}$ dengan presentase $\mathrm{Zn} \leq 40 \%$, maka kuningan dikelompokkan menjadi dua macam, yaitu :

1. Kuningan $\alpha$, dengan fasanya $\alpha$ dan mengandung $\pm 39 \% \mathrm{Zn}$.

2. Kuningan $\alpha+\beta$, dengan fasanya $\alpha+\beta$, yang mempunyai rasio $60: 40$ untuk kandungan $\mathrm{Cu}$ dan $\mathrm{Zn}$.

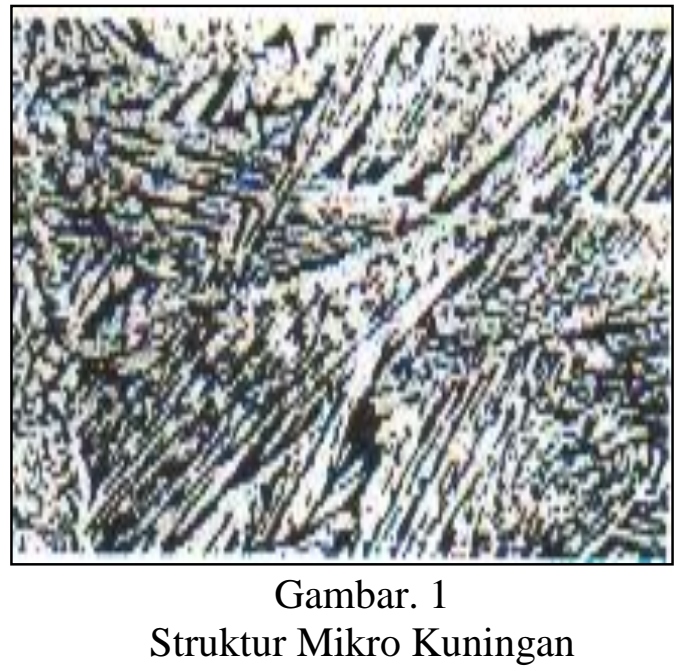

\section{Aluminium}

Aluminium merupakan unsur yang berlimpah yang ada di bumi ini dan terdapatnya selalu berupa kombinasi dengan unsur lain. Bauksit merupakan salah satu senyawa yang didalamnya terdapat unsur aluminium. Berat jenis aluminium sekitar 2,7 $\mathrm{kg} / \mathrm{dm}^{3}$ dan memiliki titik lebur $660^{\circ} \mathrm{C}$. Aluminium merupakan logam ringan mempunyai ketahanan korosi yang baik, oleh sebab itu paduan aluminium terutama dipakai pada industri pesawat terbang.
Sifat-sifat Fisik Aluminium

Aluminium memiliki beberapa kombinasi sifat-sifat teknik yang menyebabkan dipilihnya aluminium untuk bahan teknik, antara lain :

1. Berat jenis $2,7 \mathrm{~kg} / \mathrm{dm}^{3}$

Keadaan ini membuat aluminium termasuk dalam logam ringan . Oleh karena itu banyak digunakan pada konstruksi yang ringan, seperti bagian-bagian pesawat terbang dan alat transportasi lainnya.

2. Tahan korosi.

Sifat tahan korosi pada aluminium diperoleh karena terbentuknya oksida aluminium pada permukaan aluminium. Lapisan ini akan melekat pada permukaan dengan kuat sehingga akan melindungi bagian dalam.

3. Sifat penghantar panas yang baik.

4. Sifat penghantar listrik

5. Titik cair aluminium $660^{\circ} \mathrm{C}$

\section{Penguatan dengan Penghalusan Butir}

Secara mikrostruktur, logam tersusun dari butir-butir logam yang memiliki orientasi tertentu. Antara butir yang satu dengan butir yang lain dibatasi oleh batas butir ( grain boundary). Butir (grain) adalah sekumpulan partikel-partikel logam yang memiliki orientasi kristal yang sama. Makin banyak partikel-partikel yang terkumpul pada suatu lokasi dengan arah orientasi kristal yang sama maka makin besarlah butir tersebut.

Batas butir merupakan bidang yang membatasi antara partikel-partikel logam yang berbeda orientasinya. Butir yang memiliki diameter sampai 10 mikron disebut butir halus. Diameter butir sampai 50 mikron disebut butir sedang dan lebih dari 50 mikron biasanya disebut butir kasar.

Besar butir logam sangat menentukan sifat mekaniknya. Persamaan yang menghubungkan antara diameter butir dengan kekuatan luluh bahan (yield) logam dikenal dengan Persamaan Hall-Petch.

$$
\sigma \mathrm{y}=\sigma \mathrm{i}+\mathrm{k} \mathrm{D}^{-1 / 2} \quad(\text { Lit } 9 \text { hal 286) }
$$

Dimana $: \sigma y=$ Tegangan luluh

$\Sigma \mathbf{i}=$ Tegangan gesekan, yang menyatakan tahanan kristal keseluruhan terhadap pergerakan dislokasi 


$$
\begin{aligned}
\mathrm{k}= & \begin{array}{l}
\text { Konstanta pengunci, yang } \\
\text { mengukur pengaruh }
\end{array} \\
& \text { penguatan relatif dari batas } \\
& \text { butir } \\
\mathrm{D}= & \text { Diameter butir. }
\end{aligned}
$$

Dari persamaan di atas terlihat bahwa dengan semakin halusnya butir maka kekuatan luluh bahan akan semakin tinggi. Hal ini dapat dimanfaatkan untuk metoda penguatan bahan dengan mekanisme penguatan besar butir (Grain Size Strengthening). Mekanisme penguatan dengan penghalusan butir dapat dilakukan dengan berbagai cara diantaranya adalah :

1. Penambahan unsur paduan (alloying)

2. Deformasi plastis (work hardening)

3. Perlakuan panas

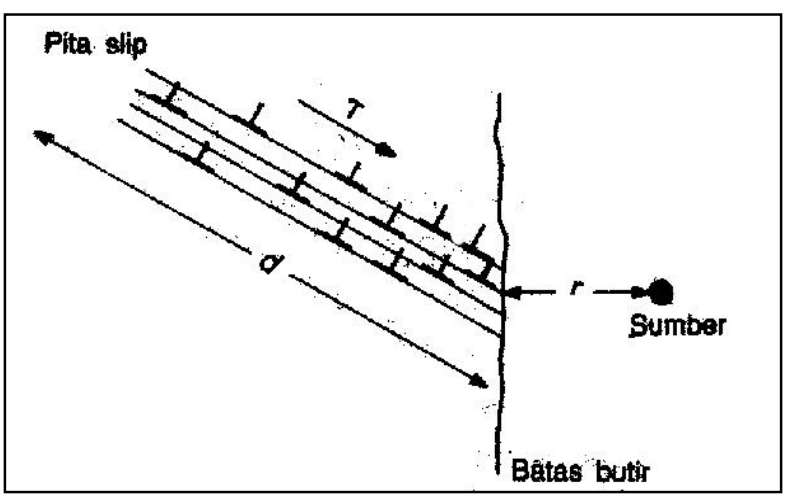

Gambar 2

Batas butir menghalangi slip

\section{Metode Penelitian}

Pada bagian ini akan diuraikan mengenai metode penelitian yang dilaksanakan menurut diagram alir pada gambar 3 .

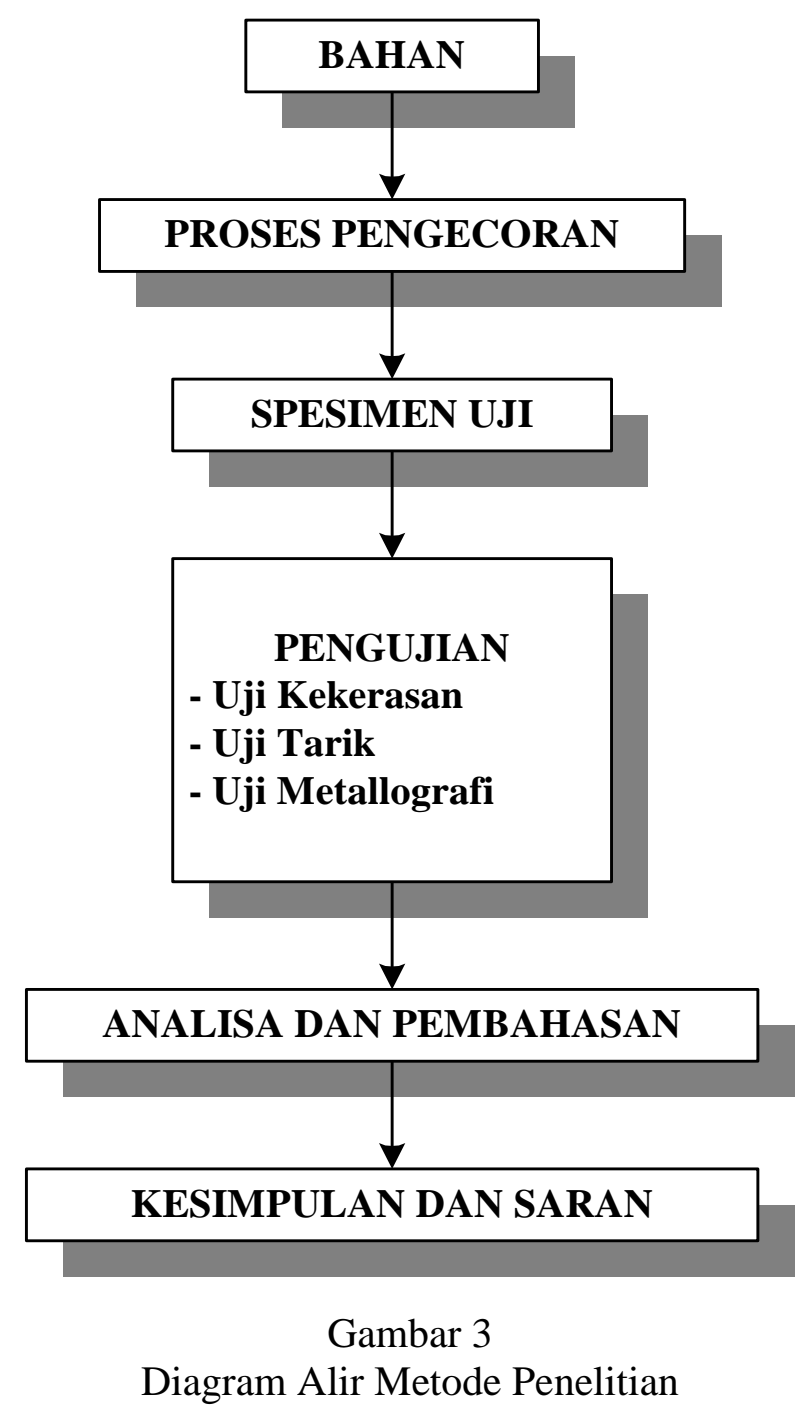

\section{Bahan dan Alat}

Peralatan dan bahan yang dibutuhkan untuk melaksanakan penelitian ini dapat dibagi menjadi beberapa bagian sebagai berikut :

A. Bahan

Bahan yang digunakan dalam penelitian ini adalah kuningan dan aluminium .

B. Peralatan untuk mengecor kuningan, yaitu :

a. Dapur kowi, digunakan untuk memanaskan dan melebur kuningan hingga suhu pengecoran

b. Kowi , yang berfungsi sebagai penampung cairan logam

c. Batang karbon, yang berfungsi untuk mengaduk coran

d. Cetakan, yang berfungsi untuk membentuk spesimen

e. Peralatan pelengkap lainnya 
C. Peralatan pengujian
a. Alat uji kekerasan Vickers type VKH-2E,Cap=50 kgf
b. Mesin uji tarik type RAT-30P Cap $30 \mathrm{Tf}$
c. Mikroskop optik type PME 3-11 B / 312 B Olympus Optical Co. LTD.

\section{Proses Pembuatan Benda Uji}

Berdasarkan aliran proses pada pembuatan coran, langkah pertama yang dilakukan adalah menentukan bahan baku. Bahan baku yang digunakan adalah kuningan dan aluminium dengan perbandingan sebagai berikut :

Tabel. I. Perbandingan Komposisi Kuningan Dan Aluminium

\begin{tabular}{|c|c|c|c|c|}
\hline \multirow{2}{*}{ No } & \multicolumn{2}{|c|}{ Kuningan } & \multicolumn{2}{c|}{ Aluminium } \\
\cline { 2 - 5 } & $(\%)$ & Gram & $(\%)$ & Gram \\
\hline 1 & 100 & 1000 & 0 & 0 \\
\hline 2 & 99 & 990 & 1 & 10 \\
\hline 3 & 97 & 970 & 3 & 30 \\
\hline
\end{tabular}

\section{Pembuatan Pola}

Pola merupakan bentuk tiruan dari benda kerja yang sebenarnya yang digunakan untuk membuat rongga cetakan. Bahan pola yang sering digunakan adalah kayu (termasuk plastik ) dan logam.

Pola yang digunakan dalam pembuatan spesimen ini adalah pola logam dengan pertimbangan agar dapat menjaga ketelitian ukuran benda cor dan penanganan cetakan menjadi lebih mudah. Gambar 4 menunjukkan bentuk dan ukuran dari pola yang akan digunakan .

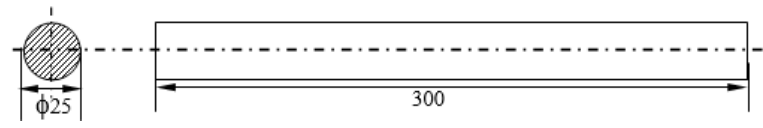

Gambar 4

Bentuk Dari Pola Logam

\section{Hasil dan Pembahasan}

Hasil dari penelitian dapat diketahui besarnya pengaruh penambahan unsur Aluminium terhadap kekerasan dan kekuatan kuningan. Data yang diperoleh dari hasil pengujian yang dilakukan selanjutnya dianalisa dan disimpulkan. Dimana dari hasil pengujian mengenai pengaruh unsur aluminium terhadap sifat mekanik kuningan didapat dua bentuk data, yaitu data nilai kekerasan dan data kekuatan tarik pada kuningan setelah dilakukan penambahan unsur aluminium dengan persentase yang berbeda.

\section{Data Pengujian Kekerasan}

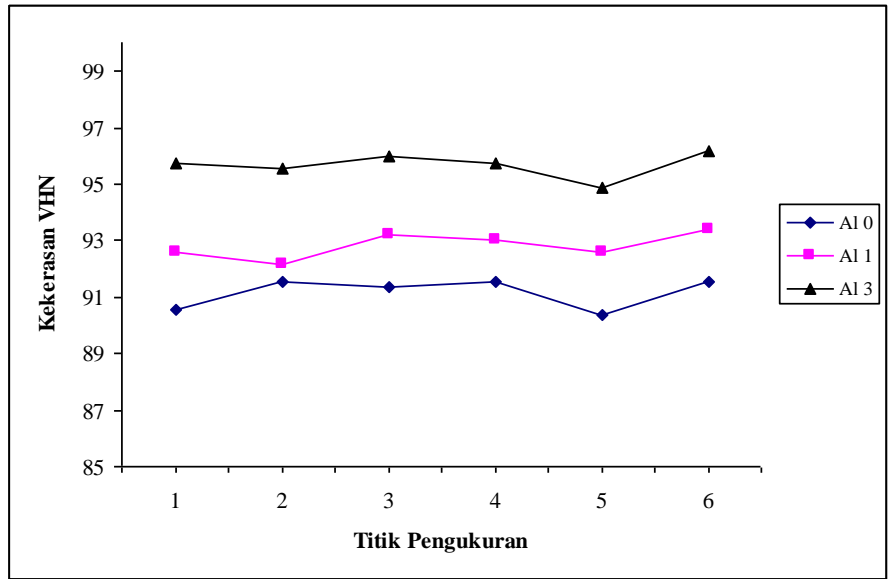

Gambar 5

Grafik Kekerasan Rata-Rata Spesimen

\section{Data Pengujian Tarik}

Tabel II. Data Hasil Pengujian Tarik

\begin{tabular}{|c|c|c|c|c|c|c|c|c|c|}
\hline $\begin{array}{l}\text { Spesi } \\
\text { men }\end{array}$ & $\begin{array}{l}\mathrm{A}_{0} \\
(\mathrm{~mm})\end{array}$ & $\begin{array}{l}\mathrm{L}_{0} \\
(\mathrm{~mm})\end{array}$ & $\begin{array}{l}\mathrm{L}_{1} \\
(\mathrm{~mm})\end{array}$ & $\begin{array}{l}\Delta L \\
(\mathrm{~mm})\end{array}$ & $\begin{array}{l}\text { Elongasi } \\
(\%)\end{array}$ & $\begin{array}{l}\mathrm{Pu} \\
(\mathrm{kgf})\end{array}$ & $\begin{array}{l}\sigma_{u} \\
(\mathrm{kgf})\end{array}$ & $\begin{array}{c}\sigma_{y} \\
(\mathrm{kgf})\end{array}$ & $\begin{array}{l}\sigma_{f} \\
(\mathrm{kgf})\end{array}$ \\
\hline AL0 & 314 & 160 & 182 & 22 & 13,75 & 8250 & 26,274 & 9,076 & 23,408 \\
\hline AL1 & 314,658 & 160 & 181 & 21 & 13,175 & 8400 & 26,696 & 9,534 & 24,312 \\
\hline AL3 & 314 & 160 & 179 & 19 & 11,875 & 8550 & 27,229 & 10,032 & 25,223 \\
\hline
\end{tabular}

\section{Hasil Pengamatan Metallografi}

Untuk mengetahui perbedaan struktur mikro tiap spesimen terhadap pengaruh aluminium yang ditambahkan kedalam kuningan, maka dilakukan pengamatan metallografi. 
Pengamatan ini dilakukan dengan menggunakan mikroskop optik type PME 3-11 B/312B Olympus Optical Co.ltd terhadap tiap spesimen yang dipoles dan dietsa dengan larutan $80 \mathrm{ml} \mathrm{HNO}_{3}$ dan $40 \mathrm{ml}$ aquades.

\section{Struktur Mikro Tiap Spesimen}

Gambar yang dihasilkan dari spesimen adalah sebagai berikut:

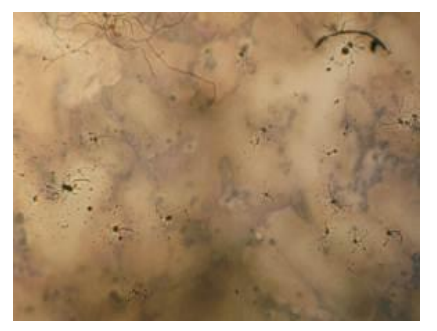

(a)

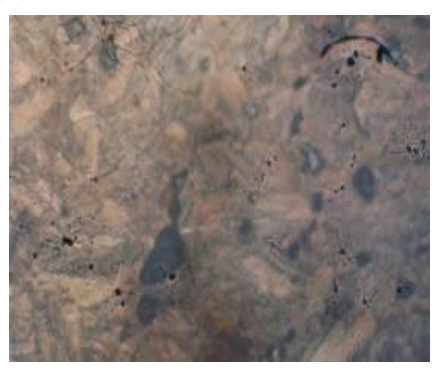

(c)

Gambar 6

Struktur Mikro Kuningan Tanpa Penambahan Unsur Aluminium (a). 0\%, (b). 1\%, (c). 3\%

\section{Pembahasan}

Dari penelitian ini dapat diketahui pengaruh penambahan unsur aluminium terhadap perubahan kekerasan dan kekuatan kuningan. Penelitian ini juga memperlihatkan perubahan struktur mikro kuningan yang telah dicampur dengan unsur aluminium.

Pada pengujian kekerasan diperoleh data bahwa spesimen kuningan mengalami peningkatan kekerasan setelah dilakukan penambahan unsur aluminium. Pengerasan ini dapat terjadi karena dislokasi mengalami kesulitan untuk bergerak dari satu butir ke butir lainya. Nilai kekerasan menjadi meningkat dari 91,152 VHN sampai 95,693 VHN.

Hasil yang diperoleh dari pengujian tarik menunjukkan bahwa kekuatan tarik kuningan meningkat dengan adanya tambahan unsur aluminium. Hal ini dapat disebabkan karena terhambatnya gerak dislokasi oleh batas butir yang akan menimbulkan konsentrasi tegangan pada ujung kelompok penumpukan dislokasi karena pengaruh tegangan dari luar dan cukup untuk memicu sumber di butir-butir di sekitarnya. Ada beberapa cara partikel halus dapat bertindak sebagai penghalang terhadap dislokasi. Partikel itu dapat bertindak sebagai partikel kuat yang tak mudah terpotong, dimana dislokasi hanya dapat bergerak dengan perubahan tajam dalam lengkungan garis dislokasi, sedangkan dilain pihak partikel tersebut dapat bertindak sebagai partikel koheren, dimana dislokasi dapat lewat tetapi hanya pada tingkat tegangan jauh diatas yang diperlukan untuk menggerakkan dislokasi. Dari hasil penelitian didapat kekuatan tarik kuningan menjadi neningkat dari 26,274 $\mathrm{kgf} / \mathrm{mm}^{2}$ sampai $27,229 \mathrm{kgf} / \mathrm{mm}^{2}$.

Konsentrasi fasa pada struktur mikro kuningan tampak lebih menyebar merata yang disebabkan penambahan unsur aluminium. Penyebaran ini menjadikan batas butir kuningan menjadi lebih halus.

\section{Kesimpulan}

$X$

Dari hasil pengujian tarik menunjukkan bahwa kuningan yang diberi tambahan unsur aluminium ternyata mengalami peningkatan kekuatan bila dibandingkan dengan kuningan tanpa unsur aluminium. Hal ini dapat disebabkan karena terhambatnya gerak dislokasi oleh batas butir yang akan menimbulkan konsentrasi tegangan pada penumpukan dislokasi.

Peningkatan kekerasan pada kuningan dengan penambahan unsur aluminium disebabkan karena dislokasi mengalami kesulitan untuk bergerak dari satu butir ke butir lainnya.

Dari pengujian struktur mikro didapatkan hasil butiran yang lebih halus dengan penambahan unsur aluminium dalam kuningan, serta terlihat konsentrasi fasa yang terbentuk lebih menyebar. 


\section{Daftar Pustaka}

[I]. Tata Suardia dan Kenji Chijiwa, “ Teknik Pengecoran Logam ", Pradnya Paramita, Jakarta, 1986.

[II]. Sriati Djaprie, “ Teknologi Mekanik “, Erlangga, Jilid I, 1990.

[III]. Van Vlack dan Sriati Djaprie, “ Ilmu Dan Teknologi Bahan ", Erlangga, Jakarta, 1987.

[IV]. Tata Suardia dan S. Saito, Pengetahuan Bahan Teknik ", Pradnya Paramita, Jakarta, cetakan kedua.

[V]. George E. Dieter, " Metallurgi Mekanik “, Erlangga, Jakarta, 1990, Edisi ketiga.

[VI]. Earl R. Parker, “ Materials Data Book “, Mc Graw Hill, California,1967.

[VII]. Smith, "Materials Science and Engineers Series - Structure and Properties of Engineering Alloys", McGraw Hill, 1993, Second Edition.

[VIII]. S. Grabowski and P. Entel, Elementary Diffusion Processes In $\mathrm{Cu}$ Zn-Al Alloy “, Universitat Duisburg, Germany.

[IX]. R.E. Smallman, “ Metallurgi Fisik Modren”, PT. Gramedia, Jakarta, 1991, Edisi keempat.

[X]. K.J. Pascoe, " An Introduction To The Properties Of Enginering Material," Van Mostrand Reinhold Co, Ltd, 1978, Third Edition. 